\title{
Surfaces
}

\section{Bibliographie Bill Readings Bibliography Bill Readings}

\section{Brian Neville et Françoise Lucbert}

Volume 6, 1996

LES ÉCONOMIES DISCURSIVES DU SAVOIR ET DE LA CULTURE DANS

LE SILLAGE DE L'OEUVRE DE BILL READINGS

THE DISCURSIVE ECONOMIES OF KNOWLEDGE AND CULTURE,

WITH CONSTANT REFERENCE TO THE WORK OF BILL READINGS

URI : https://id.erudit.org/iderudit/1064847ar

DOI : https://doi.org/10.7202/1064847ar

Aller au sommaire du numéro

Éditeur(s)

Les Presses de l’Université de Montréal

ISSN

1188-2492 (imprimé)

1200-5320 (numérique)

Découvrir la revue

Citer ce document

Neville, B. \& Lucbert, F. (1996). Bibliographie Bill Readings / Bibliography Bill

Readings. Surfaces, 6. https://doi.org/10.7202/1064847ar 
$\underline{\text { Surfaces }}$

\section{Bibliographie/ \\ Bibliography Bill \\ Readings}

Brian Neville

Françoise Lucbert

Surfaces Vol. VI. 202 (v1.0 F A - 30/12/1996) - ISSN:

1188-2492

Tout texte reste la propriété de son auteur. Néanmoins, Surfaces demande d'être citée à l'occasion de toute autre publication du texte en question.

\section{Thèse/Dissertation}

"The Restoration and the Fall of Language: The Search for Meaning in the Poetry of John Milton and Andrew Marvell." Diss. U of Oxford, 1985. 


\section{Ouvrages/Publications}

\section{Livres/Books}

The University in Ruins.

Cambridge, MA: Harvard UP,

1996.

Introducing Lyotard: Art and

Politics. London \& New York:

Routledge, 1991 (2nd. ed.

1992).

Bill Readings,

The University

in Ruins

\section{Direction d'ouvrages collectifs/ Anthologies}

Vision and Textuality (coedited with Stephen Melville).

Basingstoke: Macmillan UK, 1994; Durham, NC: Duke UP 1994.

Postmodernism Across the Ages: Essays for a Postmodernity That Wasn't Born Yesterday (co-edited with Bennet Schaber). Syracuse: Syracuse UP, 1993.

\section{Traductions/Translations}

Political Writings. By J.-F. Lyotard (editor; translated with Kevin Paul Geiman).

Minneapolis: U of Minnesota P, 1993.

\section{Essais/Essays}

\section{7}

"A Commonplace in Walter Benjamin" (with Brian Neville). Mapping Benjamin: The Work of Art in the Digital Age. Stanford: Stanford UP, forthcoming. 


\section{5}

"How Obvious is Art? Kitsch and the Semiotician." Vision and Textuality. Eds.

Stephen Melville and Bill Readings.

Basingstoke: Macmillan UK, 1994; Durham:

Duke UP, 1994. 143-146.

"Privatizing Culture: Reflections on JeanFrançois Lyotard's ' oikos '." Angelaki II.1.

"The University Without Culture." New Literary History (1995).

"Il senso e il terremoto." La Lingua di Pirandello. Ed. Enzo Lauretta. Milan: Mursia.

"Difficult Times: A Manifesto for a Postmodern Literary History." Postmodern Life. Eds.

Thomas Carmichael and Alison Lee. DeKalb: Northern Illinois UP. Reprinted in Language and Literature Today: Proceedings of the XIXth Triennial Congress of the International Federation for Modern Languages and Literatures. Vol.1. Brasilia: Universidade de Brasilia, 1996. 329-334.

"L'Université et la culture. La crise identitaire d'une institution." Trans. Shauna Falk and Marie Lessard. Spirale, avril (1995). 6.

\section{4}

"From Emancipation to Obligation: Sketch for a Heteronomous Politics of Education." Education and the Postmodern Condition. Ed. Michael Peters. Auckland \& New York: Bergin and Garvey.

"American Nightmares: The American Dream in the Age of Televisual Reproduction." Le rêve américain. Montréal: CIADEST. Reprinted in American Dream: 1930-1995. Eds. JeanFrançois Côté, Nadia Khouri, and Dominique Michaud. Ottawa: U of Ottawa P, 1996. 164-173.

"Lyotard." The Penguin Dictionary of Philosophy. Ed. Thomas Mautner. London: Penguin. 
"Hamlet's Thing." New Essays on Hamlet. Eds. Mark Thornton Burnett and John Manning. London \& New York: AMS P. 47-65.

"When Did the Renaissance Begin? The Henrician Court as Shakespearean Spectacle." Rethinking Henrician Literature. Ed. Peter Herman. U of Illinois P. 283-302.

"Caught in the Net: Notes from the Electronic Underground." Surfaces IV.

\section{3}

"For A Heteronomous Cultural Politics." Oxford Literary Review 15.1-2. 163-199. Reprinted in Constructive Criticism: The Human Sciences in the Age of Theory. Eds. Martin Kreiswirth and Tom Carmichael. Toronto: U of Toronto P, 1994.

"Be Excellent: Culture, the State, and the Posthistorical University." Alphabet City 3, special issue on "The States of Culture." 46-51.

"The End of the Political." Foreword. Political Writings. J.-F. Lyotard. Ed. Bill Readings. Trans. Bill Readings and Kevin Paul Geiman. Minneapolis: U of Minnesota P. xiii-xxvi.

"Le canon et ses suites: entre concept et figure." Théologiques 1.2 (Oct.). 39-62.

"Identity Crisis: The University and Culture." ACCUTE Newsletter.

"Le pays où rêvent les fourmis vertes: La représentation des droits territoriaux des aborigènes." Trans. Marie Lessard. L'Indien: Instance Discursive. Ed. Antonio GomezMoriana. Candiac: Balzac. 427-452.

"Milton at the Movies: An Afterword to Paradise Lost." Postmodernism Across the Ages: Essays for a Postmodernity That Wasn't Born Yesterday. Eds. Bill Readings and Bennet Schaber. Syracuse: Syracuse UP. 88-106.

"Dryden." The Johns Hopkins Guide to Literary Theory and Literary Criticism. Baltimore: Johns Hopkins UP. 216-219. 
"Lyotard." The Johns Hopkins Guide to Literary

Theory and Literary Criticism. Baltimore: Johns Hopkins UP. 478-480

\section{2}

"PseudoEthica Epidemica: How Pagans Talk to the Gods." Philosophy Today 36.4 (Winter). 377-388.

"Sublime Politics: the End of the Party Line." Modern Language Quarterly 52.4 (Dec.). 409-425.

"Pagans, Perverts, or Primitives: Experimental Justice in the Age of Capital." Judging Lyotard. Ed. Andrew Benjamin. Warwick Studies in Philosophy and Literature. London \& New York: Routledge. 168-191.

"An Age too Late: Milton and the Time of Literary History." Exemplaria 4.2 (Fall). 455-468.

\section{1}

"Translatio et Littérature Comparée. La terreur de l'humanisme européen/Translatio and Comparative Literature: The Terror of European Humanism" simultaneous French and English publication. Surfaces I.

"Feminism and the Exquisite Corpse of Realism" (with Stephen Melville). Strategies 4-5. 242-288.

\section{0}

"Why is Theory Foreign?" Theory Between the Disciplines: Authority, Vision, Politics. Eds. Martin Kreiswirth and Mark Cheetam. Ann Arbor: U of Michigan P. 77-97.

\section{9}

"Canon and On: From Concept to Figure" The Journal of the American Academy of Religion 57.1 (Spring). 149-172. 
"The Deconstruction of Politics." Reading de Man Reading. Eds. Lindsay Waters and Wlad Godzich. Minneapolis: U of Minnesota P. 223-243.

\section{5}

"On the New Forcers of Conscience: Milton's Critics." The Oxford Literary Review 7.1-2. 132-147.

\section{Comptes Rendus/Book Reviews}

Rev. of Cultural Capital, by John Guillory. Modern Language Quarterly 55.3 (Sep. 1994).

Rev. of Lectures d'enfance, by J.-F. Lyotard. Surfaces II (1992).

"Getting Hip to the Square: A. J. Greimas and the Nature of Meaning." Rev. of A. J. Greimas and the Nature of Meaning, by Ronald Schleifer. Genre 22.3 (Fall 1989). 329-331.

\section{Autres publications/Other Publications}

Surfaces: revue électronique. Rapport pour le Ministère de l'enseignement supérieur et de la science, programme de soutien aux activités de développement de la culture scientifique et technique (1992).

Accueil Surfaces | Table des matières | Recherche Surfaces Home Page | Table of Contents | Search

PUM | Livres | Revues | Publications électroniques | Vente et distribution 